\title{
THE QUALITY OF LIFE OF GAY COMMUNITY IN TULUNGAGUNG, EAST JAVA, AND ITS ASSOCIATED BIOPSYCHOSOCIAL FACTORS
}

\author{
Dily Ekasari'), Argyo Demartoto²), Bhisma Murti1) \\ 1) Masters Program in Public Health, Universitas Sebelas Maret \\ ${ }^{2)}$ Department of Sociology, Faculty of Social and Political Sciences, \\ Universitas Sebelas Maret
}

\begin{abstract}
Background: Little is known about the quality of life of gay men and lesbians living in Indonesia. Recent research has shown that lesbian, gay, and bisexual (LGB) adults have greater psychiatric morbidity and therefore lower quality of life than their heterosexual counterparts. This excess morbidity and lower quality of life are related to exposure to stressors, such as prejudice, discrimination, and violence. Stigma and discrimination that are experienced by gay community have long been documented to occur in Indonesia, including Tulungagung District, East Java. This study aimed to examine the quality of life of gay community in Tulungagung, East Java, and its associated biopsychosocial factors.

Subjects and Method: This was a cross-sectional study conducted in Pelangi Gay Community, Tulungagung District, from October to November 2017. A total sample of 181 gays was selected by stratified random sampling. The exogenous variables were sexual behavior, family income, peer support, stigma, and discrimination. The endogenous variables were family support and quality of life. The data were collected by questionnaire and analyzed by path analysis.

Results: Better quality of life was positively affected by safe sexual behavior $(b=$ $1.32 ; 95 \% \mathrm{CI}=0.18$ to $2.46 ; \mathrm{p}=0.023)$ and strong family support $(\mathrm{b}=1.47 ; 95 \%$ $\mathrm{CI}=0.42$ to $2.51 ; \mathrm{p}=0.006)$. Strong family supportwas positively affected by family income ( $b=1.62 ; 95 \% \mathrm{CI}=0.97$ to $2.27 ; \mathrm{p}=0.001)$. Better quality of life was positively affected by participation in peer support program $(b=2.84 ; 95 \% \mathrm{CI}=$ 1.77 to $3.91 ; \mathrm{p}=0.001)$, freedom of stigma $(\mathrm{b}=1.11 ; 95 \% \mathrm{CI}=-0.04$ to $2.26 ; \mathrm{p}=$ $0.060)$, and freedom of discrimination $(\mathrm{b}=1.43 ; 95 \% \mathrm{CI}=0.37$ to $2.48 ; \mathrm{p}=$ 0.008).

Conclusion: Safe sexual behavior and strong family support have direct positive effect on the quality of life of gay community. Stigma and discrimination have indirect effect on lower quality of life of gay community.
\end{abstract}

Keywords: quality of life, sexual behavior, family support, stigma, discrimination, gay

\section{Correspondence:}

Dily Ekasari. Masters Program in Public Health, Universitas Sebelas Maret, Jl. Ir. Sutami 36 A, Surakarta 57126, Central Java. Email: dilyekasari89@gmail.com. 